\title{
14 Polymedia communication and mediatized migration: an ethnographic approach
}

\begin{abstract}
This chapter investigates the cumulative consequences of new communication technologies for the phenomenon of migration. Drawing on a five-year-long comparative and multi-sited ethnography of long-distance communication within Filipino transnational families I demonstrate that the recent convergence in new communication technologies has profound consequences not just for the migrants and their left-behind families but for the phenomenon of migration as a whole. Although new media cannot solve the fundamentally social problems of family separation, they have become integral to how these relationships are experienced and managed. Despite the transnational asymmetries in infrastructure and media literacy, the increasing availability of transnational communication is used as a justification for key decisions relating to migration or settlement in the host country. This discourse, which ultimately normalizes migration decisions, is also evident at an institutional level. The chapter brings together research with institutional actors as well as migrant families and shows that transnational communication through new media - understood as an environment of polymedia - has become implicated in making female migration more socially acceptable while ultimately influencing patterns of migration. By bringing together an analysis of interpersonal communication as mediation and social change as mediatization the chapter shows that media do not just add a new dimension to the phenomenon of migration - they transform it altogether. The chapter also outlines the distinct contribution of an ethnographic approach to mediatization.
\end{abstract}

Keywords: migration, transnational families, interpersonal communication, family relationships, social change, media anthropology, ethnography, new communication technologies, media environments, polymedia, convergence

The field of migration research offers fertile ground for the investigation of the consequences of new media. The continuing rise in global migrations is a key phenomenon for contemporary societies affecting both sending and host countries. Migrants as transnational subjects can be sophisticated users of new communication technologies in order to keep in touch with left-behind families (Madianou and Miller 2012), or to improve their life chances before and post migration (Elias and Lemish 2009; Hiller and Franz 2004). Contrary to popular stereotypes which cast migrants as perpetually destitute and information poor, recent research points out that certain groups of economic migrants (though certainly not all) are early and avid adopters of new technologies (Fortunati, Pertierra and Vincent 2012; Mad- 
ianou and Miller 2012; Qiu 2009) who are prepared to invest in hardware and face the necessary connection costs. Of course, many other social groups are, or are claimed to be early adopters of new media. What makes some migrants' experience significant is their dependency on new technologies, for example, under conditions of family separation. While for most people family life will involve a combination of mediated and non-mediated interactions (Clark 2012) for many migrants family life is almost entirely dependent on communication media (Madianou and Miller 2012). The experiences of such migrants exemplify a form of "media life" (Deuze 2012).

Traditionally, most research on media and migration has focused on the question of representation - the ways migrants are (mis)representend in various formats of news and popular culture (Moore, Gross and Threadgold 2012) and the way such representations reproduce racism and xenophobia in society (Hartman and Husband 1973; van Dijk 1991; Philo, Briant and Donald 2013). Although the issue of representation of difference is of unquestionable political and social importance, it does not address the ways migrants themselves become creative users, or producers of new media not only to keep in touch at a distance, but also in order to develop their own content and take control over their representation. The migrants' perspective is very important as it reveals the issues that matter to them the most as well as the difference that the media make (or not) to their own lives. A number of audience-centred studies (Gillespie 1995; Georgiou 2006; Madianou 2005b; Sreberny 2005; Sun 2009 among others) have contributed important insights with regards to questions of identity, belonging, and exclusion. Less common are studies that bring together the migrants' perspectives as well as those of other institutions and relevant stakeholders, such as government representatives, non-governmental organizations, and telecommunications companies themselves. Adopting a wider analytical lens helps to address the cumulative consequences of the media for migrants themselves and for the phenomenon of migration more broadly. What does it mean for a migrant woman from the Philippines to leave the webcam on for the whole weekend in order to achieve a sense of co-presence with her left-behind children? What are the implications of "ambient co-presence” achieved via constantly updating and checking social networking sites on one's smartphone (Madianou forthcoming 2014)? Do these communication practices have any implications for decisions relating to migration or settlement in host countries (Madianou 2012) thereby shaping patterns of migration?

This chapter addresses the cumulative consequences of new media for the phenomenon of migration. Drawing on a long-term ethnography (2007-2011) of transnational communication between UK-based migrant women and their leftbehind children in the Philippines, I argue that new media are more than channels for personal communication while they have significant consequences which affect the whole process of migration, including the motivations to migrate and settle abroad as well as the justifications for such decisions. The increasing taken-forgrantedness of transnational communication made possible because of the avail- 
ability and affordability of new media emerges as an important catalyst for the transformation of patterns of migration and migratory experiences.

The Philippines, one of the most intensely migrant societies, has come to exemplify the phenomenon of transnational mothering and left-behind children due to the prevailing feminized migration flows (Asis 2008; Parreñas 2001). The research on which this chapter is based investigated the role of the ever-proliferating new communication technologies for Filipino families whose members experience extended periods of separation. What makes the Philippines particularly interesting for examining the convergence of new media and migration is that the country is at the forefront of new media developments, especially mobile phones (Madianou and Miller 2012; Pertierra 2010). The primary aim of this chapter is not to report on the findings of this research as this has been done elsewhere (see Madianou 2012 and Madianou and Miller 2012), but to address the deeper implications of the increasingly ubiquitous presence of new media in transnational family life.

As a theory of social change mediatization provides a very suitable framework for assessing the cumulative consequences of new media on migration. There are, of course, different traditions of mediatization research (for a discussion see Couldry and Hepp 2013; Lundby 2009b). This chapter develops a hybrid approach that draws on the social constructionist tradition of mediatization (Couldry 2012; Couldry and Hepp 2013; Hepp 2012, 2013) as well as on the growing field of media and digital anthropology (Ginsburg, Abu-Lughod and Larkin 2002; Horst and Miller 2012; Madianou and Miller 2012). Given the parallels between the two traditions there is scope for theoretical convergence. My integrative approach brings together the migrants' own perspectives and the wider social and institutional contexts. Media anthropology has traditionally resisted the temptation to isolate the focus on media texts, production or consumption and has instead insisted on "following the thing" (Marcus 1995) - that is, following the subject of study and its relationships in a multi-sited, transnational context. Adopting a wide-angle approach and bringing together different levels of analysis is essential for capturing social change. There are strong parallels here with mediatization research and some earlier work on mediation (Livingstone 2009; Silverstone 2005; Martin-Barbero 1993). Apart from highlighting the cumulative consequences of new media for migration, this chapter will also discuss what a media anthropology perspective can contribute to a mediatization approach.

Although the title of the chapter refers to mediatized migration it is evident that migration is too complex and diverse a phenomenon for a single type of social change to occur. The Philippines, of course, is one of the most intensely migrant societies globally, but it cannot possibly represent all types of migration flows which can be long term, short term, or circular; voluntary or forced; documented or undocumented to name a few (Castles and Miller 2009). Moreover, the context of the destination country is very important in shaping migration experiences and 
outcomes. For example, migrations from the Philippines to the UK and the US are fundamentally different (Madianou, in preparation). Also significant are the media which are available to each population. The Philippines, for example, is at the forefront of mobile media developments (Pertierra 2010) and this particular media environment - different for other countries in the developing world - shapes the contours of mediatization. The argument developed here concerns a specific type of migration, that is predominantly female economic migration from the Philippines to the UK which is often described as short-term and individual, often involving family separation at the nuclear level. Migrants are typically employed in the care sector occupying different types of low-skilled (domestic work) and highskilled (nursing) jobs although even those in low-skilled jobs are often secondary school- or college-educated prior to migration. The characteristics of this migration are presented in detail in section 3 so this brief discussion only serves to indicate that the present argument on the mediatization of migration is primarily related to the particular migration flow I have been working with and, possibly, to other similar flows. Although it is conceivable that some of the arguments presented here could apply to very different migration flows, this will need to be the focus of a comparative research inquiry.

This chapter discusses the ways in which members of transnational families maintain personal relationships at a distance and the implications this has for the phenomenon of migration more broadly. The research reported here points to two parallel processes of mediatization: the mediatization of family life through practices of parenting at a distance and the mediatization of migration. I will here only focus on migration research although I fully recognize that social change or mediatization occurs at the level of relationships themselves (for a discussion on motherhood, individualism and ambivalence see Madianou 2012).

The following two sections are dedicated to the key literatures informing this chapter, namely research on media and migration; and mediatization. Following that is a discussion of Filipino migration with special reference to the UK as destination/host country before moving on to the research design. The empirical discussion brings together the perspectives of various stakeholders involved in the process of migration. We will first consider the institutional and public discourses regarding new communication technologies in the context of migration followed by the perspective of the migrant women and their left-behind children. This is supplemented by a consideration of mediated communication in the context of migration before addressing the social transformation of migration through new media.

\section{Media and migration: the story so far}

Migration and media research are flourishing interdisciplinary fields. Although there has been a significant body of research on media and migration within media studies, migration research has largely ignored the media (some notable excep- 
tions include Baldassar 2008; Vertovec 2004). As a result the following paragraphs will primarily focus on work within the field of media research, some of which has had an impact in social science more broadly. Research on media and migration has typically fallen into one of the three dominant approaches in media studies, either focusing on text/representation, production, or reception/consumption. Textual research has mainly addressed the important question of representation of difference and the reproduction of racism in Western contexts. The debates around representation of difference are very important as they point to overt or banal yet always pernicious - forms of xenophobia and racism which are becoming increasingly prevalent (Hartmann and Husband 1973; Kaye 2001; Loshitzky 2010; Moore, Gross and Threadgold 2012; van Dijk 1991). Debates about immigration have always been politically sensitive if not controversial, and this trend has been exacerbated by the global economic downturn since 2008 during which migrants have often been scapegoated for the rise in unemployment and other social problems. The steep rise of xenophobia and racism in Europe coupled with the rise of the radical right (Guibernau 2010) are often attributed to the negative media coverage of immigrants and asylum seekers (Kaye 2001; Moore, Gross and Threadgold 2012).

The other tradition of media research focuses on production - the ways in which journalists covering immigration understand, research, and report on the subject. Fewer studies have emerged from this approach - a notable recent exception is the groundbreaking work of Benson (2013) who developed a cross-country (French and US) comparison of journalistic accounts on reporting immigration. Within the production approach we also find studies which have focused on the production of migrant and community media by migrants themselves (Husband 2005). Kosnick (2007) has developed an exemplary ethnography of Turkish media in Germany which also took into account media discourse. Recent years have seen the development of research that examines the rise of migrant blogs or production of content on social media as part of their efforts to gain visibility and amplify their voice in the public domain (Franklin 2001; Mitra 2001; Siapera 2005).

Transnational audience research has been expanding over the past two decades encompassing significant work on reception as well as consumption and wider cultural practices (Georgiou 2006; Gillespie 1995; Madianou 2005a; Sun 2009 among others). Recent studies on media consumption in the context of diasporas and immigrant groups have pointed to the changing and dynamic nature of ethnic and cultural identities; the diversity within ethnic groups, for example along lines of gender or class (Georgiou 2006; Hegde 2011; Sreberny 2005); the multiplicity of belongings; migrants' social (rather than merely ethnic) uses of media (Robins and Aksoy 2001; Madianou 2005b); and finally, the boundary-making role of the media contributing to processes of exclusion from public life (Madianou 2005b) or conditions of subjugation (Sun 2011). Media consumption emerges as a key site in the symbolic articulations of identities which are recognized as processes of negotia- 
tion and ambivalence, a point made early on by Gillespie (1995). Identity - a term that can be too bounded to explain the dynamism and fluidity of transnational phenomena - dominated the agenda in this earlier generation of transnational audience research (for a discussion see Madianou 2011).

The advent and proliferation of new media has opened up the research agenda moving beyond the preoccupation with identity to include questions around transnational practices and relationships (Baldassar 2008; Vertovec 2004). Studies have focused on a range of practices from the instrumental uses of new media as part of the preparation for migration (Hiller and Franz 2004) and the ways in which new media help close knowledge gaps (Elias and Lemish 2009) to the ways in which transnational communication through new media helps revitalize diaspora connections (Miller and Slater 2000) or contributes to the entrenchment of asymmetrical power relationships (Sun 2011). This second generation of studies has paved the way for the mediatization perspective discussed here although most work rarely moved beyond the reporting of particular cases. There are some notable exceptions which have made broader arguments for the consequences of media for migration and wider social change. For example, Qiu's (2009) work on (internal) migrant workers in China argues that information technologies are implicated in class formation. Despite new media's opportunities for social capital for the “information have-less", new media can also be responsible for entrenching social positions and hierarchies (Qiu 2009). Although he doesn't draw on mediatization, Qiu's argument on the way media are implicated in social class formation is remarkably close to the mediatization approach discussed in this volume. Madianou's earlier work (2005a) on minority exclusion and silencing as the result of cumulative processes of mediation represents another example. Diminescu (2008) also adopted a wide lens approach when making a broad argument about "the connected migrant" while recent work by Hepp (2013) on "communicative figurations" and Wallis (2013) on gender and mobility in China also represent efforts to address wider social transformations.

\section{Mediatization, mediation and polymedia}

Mediatization has emerged as one of the most exciting and promising intellectual developments in media and communications research in recent years. Mediatization represents the convergence of efforts to capture the cumulative social consequences of media. Various terms and approaches have previously aimed to do so including mediation (Silverstone 1999; Martin Barbero 1993; Livingstone 2009) and mediazation (Thompson 1995) while parallel efforts can be traced in research within media and digital anthropology (Ginsburg, Abu-Lughod and Larkin 2002; Horst and Miller 2012). Consensus is currently emerging around mediatization as the most suitable term to capture the deeper implications of what it means to live 
in intensely mediated environments. In my past research I drew on a mediation framework (see also Silverstone 2005) - not dissimilar to the mediatization approach proposed here - to argue for the boundary-making role of the media in the context of exclusion and belonging in the nation-state (Madianou 2005a). Here I argue, following other scholars, that a terminological differentiation between mediation (a term which can be too ambiguous given its various meanings in social theory) and mediatization is a useful way forward - both terms are retained, each serving a distinct purpose.

This chapter broadly draws on the social constructionist perspective on mediatization (Couldry and Hepp 2013) as well as a media anthropological approach. As noted earlier, ethnographies within the rapidly expanding field of media and digital anthropology have also often been taking a wide-angle approach to media, not just focusing on a specific moment (for example the production or consumption of a specific text) but trying to describe a wider process of social change. This wide-angle approach is often achieved through multi-sited ethnographies (Marcus 1995) where researchers "follow the thing", that is the subject of research, transnationally. Media ethnographies have moved beyond a presentist perspective and often include historical accounts (see Larkin 2002) as well as the perspective of multiple actors from institutions, the state, and individuals as well as the media and technologies themselves. Importantly, ethnographic fieldwork because of its open-ended and inductive nature can reveal surprises (Strathern 1996) and so the unexpected consequences of the media. Given that social change is often unpredictable, such insight is invaluable for a mediatization approach. One of my secondary aims in this chapter is to highlight the ways in which media anthropology can inform mediatization theories.

This anthropological perspective is compatible with the social constructionist approach to mediatization which emphasizes the role of media in the social construction of reality (Couldry and Hepp 2013; Berger and Luckmann 1967). In this vein, mediatization aims to reveal both how the social is captured in the media and how in turn the media have "a contextualised consequence for the overall process of the social construction of reality" (Couldry and Hepp 2013: 196). This approach, which echoes Silverstone's earlier conceptualization of mediation (1999 and 2005) as a dialectical process centred on the "circulation of meaning", is more open than the concept of "media logic" which has dominated the institutional approach to mediatization (Hjarvard 2008, 2013). The inevitably singular notion of "a logic" seems less suited to capture processes of convergence as media, technologies and practices continually intersect (for a discussion see Lundby 2009a). Recent research points to the conceptualization of media as environments with "media ecologies" (Horst, Herr-Stephenson and Robinson 2010, among others) and "polymedia" (Madianou and Miller 2013) representing two such efforts. Additionally, social life (and social change) is often messy and unpredictable and thus not always subject to "a logic", however appealing that might be. What we'll see here 
is that mediatization does not have a pre-determined consequence; it's the result of the mutual shaping of technology and social contexts. The benefit from comparing migrations from the same country (Philippines) but to different destination countries (UK and US) which have differing legal frameworks and labour markets reveals that media change is dependent on the social contexts (Madianou, in preparation).

If mediatization is the framework to capture social change then is there still analytical value in the notion of mediation? I argue that retaining both terms is useful as each can do a different kind of analytical work. Couldry and Hepp (2013: 197) describe mediation as "the process of communication in general" following Krotz (2009) for whom mediation can simply help distinguish between mediated and face-to-face communication. I argue that things are a bit more complex than that given that even face-to-face communication is socially mediated (one can think of language as the most fundamental form of mediation). A crisper definition of mediation matters for the present chapter as its thesis draws on a study of mediated interpersonal communication and its wider social consequences.

At a very fundamental level mediation is the process of communication. This is a useful starting point, but it is clear that mediated communication takes different guises and shapes depending on the media and platforms employed. Communication media introduce structural and technological parameters in human interactions. Different media have different affordances (Hutchby 2001; see also Baym 2010) allowing users some interactions and preventing others. In other words, interactions through social media, or email, or an environment of polymedia (Madianou and Miller 2013) will be structured differently. In order to understand mediation we need a socio-technical approach that is attentive both to the architectures and affordances of specific platforms and to the social dimension of human relationships. Rather than implying that affordances introduce a version of media logic at the level of mediation, I argue that mediation requires a combined understanding of technological form and the social shaping of technology (MacKenzie and Wajcman 1999). I propose that the theory of polymedia (Madianou and Miller 2013) can offer this approach.

Polymedia understands media as part of a composite environment within which each medium is defined relationally to all other media. In the past, when users mainly had access to one medium - say, letter writing - to keep in touch, we observed that the particular medium would shape interactions in specific ways. For example, the temporality of letters would cause frustration as "news" was actually one month old (Madianou and Miller 2011). By contrast, today users can choose from a plethora of media and platforms; what one platform cannot achieve can be accomplished by another. Increasing convergence intensifies the switching between platforms as is evident in research with smartphone users (Madianou 2014). Polymedia pays attention to the ways in which users exploit the differences among media in order suit their interactions and manage their relationships. 
Assuming users have unconstrained access to and can skilfully use at least half a dozen communication media, the choice of one medium (for instance, email) over another (say, Skype) acquires communicative significance (for example, a user may wish to introduce some distance in the communication context exploiting the temporal structure of email). The recognition of media as an environment and the emphasis on the ways in which users navigate this environment can provide a magnifying lens revealing the inner workings of mediation. Polymedia can provide an analytical framework to unpack mediation - a term often criticized for being too vague or abstract. This matters because mediatization only occurs because of mediation - so to understand the latter is essential for understanding the former.

In sum, this chapter adopts a hybrid model of mediatization drawing on the social constructivist tradition as well as media anthropology. Mediatization as a theory of media and social change is differentiated from mediation which is understood as the analysis of technologically mediated processes of communication. The sociotechnical theory of polymedia (Madianou and Miller 2013) helps unpack the workings of mediation by providing an analytical framework to reveal the ways users navigate the environment of new communication technologies.

\section{The empirical and research contexts}

This chapter reports on empirical work with Philippine transnational families. With over $10 \%$ of the population working abroad and over one million migrants (equivalent to 3,500 daily departures) deployed annually (Asis 2008) it is hard to think of a more intensely migrant society than the Philippines. Remittances reached 24 billion USD for $2012^{1}$ making the Philippines one of the top three remittance-receiving countries globally, behind China and India, both considerably larger countries (Jha, Sugiyarto and Vargas Silva 2009). The dependency of the Philippine economy on remittances explains why migration has become a clear economic policy for the Philippine government (Acacio 2008; Asis 2008) as the state actively promotes and regulates migration. Ever since the years of the martial rule, migrants have been hailed as "the heros of the Philippine economy" (Asis 2008). In recent years, dedicated government agencies identify needs in the global labour market and then actively recruit, train, and deploy Filipino workers. The Philippine government has signed bilateral agreements with countries, especially in the Middle East, to provide them with workers usually on short-term contracts. The one million annual deployment figure quoted above was an official government target (Asis 2008). The demand for care and domestic work in what is called the "global north" has been one of the factors contributing to increased female migration (Parreñas 2001). So although in previous decades Philippine migration

$1 \mathrm{http} / /$ theguardian.com/global-development/2013/jan/30/migrants-billions-overshadow-aid 
was predominantly male with emphasis on seafaring and manual labour, in recent years women are as, or more likely, than men to migrate. Given that many of these female migrants are mothers the Philippines has come to exemplify the phenomenon of transnational mothering (Hondagneu-Sotelo and Avila 1997; Hochschild 2000; Parreñas 2005).

Female migration and transnational mothering has been a source of controversy in Philippine society. Although the government promotes and encourages female migration there are strong voices in Philippine society which oppose the family separation this often entails. Interestingly, similar concerns are not expressed for male migrants who presumably are as likely to be fathers separated from their children, confirming the prevalence of traditional gender roles and stereotypes about motherhood and mothering as "the light of the home" (ArellanoCaradang, Sisin and Caradang 2007). Although there are precedents of internal migration involving women who left their island communities to seek employment as maids in Manila, female migration remains contested. The national press is full of references to the social costs of separation and "bad mothers" who leave their children behind, while popular culture is awash with stereotypes of troubled youth who grow up without maternal love and care (see Parreñas 2008). Popular films such as $A_{n a k}{ }^{2}$ (the Tagalog word for child) portray a left-behind daughter who falls into a world of vices after her mother leaves for Hong Kong. Migrant women are caught in the midst of contradictory discourses that simultaneously brand them "bad mothers" and "heros of the economy". My ongoing research with Filipina migrant women focuses on how they negotiate these contradictory discourses and articulate their own personal and maternal subjectivities through their everyday practices, whether mediated or unmediated.

The UK is the sixth most popular destination for Filipino workers (POEA 2009), officially estimated at just over 200,000 although the real number is likely to be higher than that. Many migrants arrived between 1999 and the mid-2000s as the UK's National Health Service systematically recruited nurses from the Philippines. The UK Filipino population also includes domestic workers and nannies who arrived via the Middle East and caregivers who typically came to the UK on student visas and therefore do not appear in the official statistics. Their strong presence in the care sector suggests that the UK Filipino population is strongly female as confirmed by earlier statistics (POEA 2005). Although there are no official data, my long-term involvement with the Filipino communities in England suggests that these migrants tend to be well educated often with college degrees which are common even among domestic workers. Although there are occupational divides which map onto digital literacy and exclusion - nurses, for example, are much better connected than domestics (as are their largely urban middle-class families

2 Anak was a very popular Filipino film released in 2000 and directed by R. Quintos featuring the local film star Vilma Santos. 
back home) and thus better equipped for long distance parenting - the arrival of smartphones and cheap netbooks seem to open up the opportunities for transnational communication for even the least privileged of migrants within this group. Broadly speaking, many Filipino migrants in the UK (though certainly not all) come from what would be considered middle-class backgrounds confirming migration patterns to other destinations (see Constable 1999), although the notion of middle class in the Philippines does not entail the same degree of security as in Europe or the US (Parreñas 2001). This confirms a pattern in migration research that migrants need to already possess the necessary economic, social, and cultural capital in order to undertake the expensive project of migration (Portes and Rumbaut 2006). This observation, of course, contrasts starkly with phenomena such as involuntary migration or refugee experiences where social exclusions, including digital, are very profound. Acknowledging the characteristic Filipino migration to the UK (a group diverse in itself) matters for a chapter on the mediatization of migration. The ways this particular migration is transformed because of the increasingly ubiquitous presence of new communication technologies depends on its defining parameters and prevailing issues, a point to which I will return later on.

The research which informs this chapter consists of participant observation and interviews which took place in three waves between 2007 and $2010 .^{3}$ The first period of research (2007-2008) was UK-based and consisted of 53 interviews with Filipino migrants, mainly women with children left behind. During this time we developed links with and spent time at Filipino associations and centres in London and Cambridge. This first research phase was followed by fieldwork in the Philippines during 2008/9 consisting of 53 in-depth interviews and participant observation with the (young adult) children of some of these mothers as well as other leftbehind children. During this period we also met several other participants (family members, carers, and younger left-behind children) as part of the ethnographic encounter while I also interviewed representatives from government agencies and regulatory bodies dealing with migration as well as officials from migration agencies, advocacy groups, and telecommunications companies. I also attended the mandatory Pre-Departure Orientation Seminars organized by the Philippine Overseas Employment Agency for migrants prior to their deployment to the UK. On returning from the Philippines, I re-interviewed and maintain contact with 13 of the initial informants. In total, 106 participants were interviewed (several of whom more than once) and we were able to pair 20 mothers and children.

This research has traced participants involved in different aspects of the migration process. The empirical section will begin with a discussion of the public and

3 Fieldwork, especially in the early stages of the research, was conducted jointly with Daniel Miller. I would like to acknowledge the support of the ESRC in funding the study 'Migration, ICTs and the Transformation of Transnational Family Life' (RES-000-22-2266). 
institutional discourses regarding new media in the context of migration and family separation. Such accounts reveal the wider social assumptions about the role of communication technologies in the context of family separation. We will observe the optimism regarding the arrival of new media, especially mobile phones, for alleviating the social costs of migration. We will then contrast the perspective of migrants as well as their left-behind children. Contrasting the two will allow us to assess the success of transnational communication. Bringing together these perspectives allows us to observe the circulation of discourses on migration and transnational communication (cf. Silverstone 1999) and the implications this has for the phenomenon of migration.

\section{The institutional perspective}

As a theory of social change mediatization necessitates a wide-angle approach which in this particular research was greatly informed by media anthropology. As a study of new media and transnational families the research reported here had to move beyond the narrow focus on new media use and examine the wider social, political, historical, cultural, and economic contexts. This explains the transnational focus of the research as well as the inclusion of various stakeholders, from government agencies dealing with migration to telecommunications companies. I will specifically focus on these two here, beginning with the government agencies which, as already mentioned in the previous section, are pivotal in encouraging and regulating migration.

The government sponsored "pre-departure orientation seminars" have become an essential part of the Filipino migration experience. These are mandatory for all migrants before deployment and are typically organized by the dedicated government department dealing with emigration. The Philippine Overseas Employment Administration (henceforth POEA) issues all visas and contracts and these will typically be signed on the successful completion of a pre-departure orientation seminar. These are usually one-day long and consist of practical information about the destination country as well as advice about conduct and behaviour.

I attended such a workshop in the crowded and labyrinthine POEA building in Manila in January 2009. The workshop was aimed for migrants departing to Europe - including the UK - and the overwhelming majority of participants in that workshop were women who were taking up care and domestic jobs. A whole section of the workshop was dedicated to the migrants' responsibilities to the leftbehind family which included the duty to keep in touch. In the following extract the workshop leader takes the mobile phone - and thus the availability of transnational communication - for granted: “there's no excuse not to communicate”.

"And you have a duty to your family. Who are married? Raise your hands. [Do not] forget about your family in the Philippines. [...] because your family is the reason why you're leaving 
the country. You're providing financial and moral support to your family in the Philippines. And you have to communicate. You have to communicate with your family as often as you can. There's no excuse not to, because we all have cell phones now. In the previous years, OFWs [Overseas Foreign Workers] didn't have cell phones. How did they communicate? They'd send letters because overseas calls were very expensive. Sometimes they'd record their voices. The families here would listen to them on radio through cassette tapes. But shipping takes a while. It takes one month, two months to send something to your loved ones. But nowadays, there's no excuse anymore. You have the cell phone. You can call your loved ones. You cannot abandon your families, okay?" Seminar leader, Pre-departure orientation seminar (PDOS), Philippine Overseas Employment Agency (POEA), Manila, January 2009

Similarly, the Overseas Workers Welfare Administration (henceforth OWWA), the other major government unit dealing with migration and especially the migrants' welfare, recognizes the importance of transnational communication and has developed a dedicated digital literacy training programme for migrants and their leftbehind families. The Tulay programme (tulay meaning bridge in Tagalog) was developed in partnership with Microsoft and takes place in Community Training Learning Centres (CTLC) throughout the country as well as in international destinations with significant Filipino populations, such as Hong Kong. The officer in charge of the training programme was very optimistic and spoke with certainty about the ability of the Internet and webcam in particular to bring the families together.

"So this is about training. It gives them a way to communicate across the distance because you see the problems of our OFWs; they are being lonely because they cannot see their loved ones. But because of the webcam, they can now see their loved ones everyday. And of course it keeps certain bonds with the family because of these internet facilities." Tulay programme officer, OWWA, Manila January 2009

Such optimism is echoed by representatives of mobile phone companies themselves which now recognize the importance of the potentially lucrative migrant market. Mobile telephony is very developed in the Philippines which is popularly labelled as the texting capital of the world with over 1.4 billion SMS messages sent each day (Reuters 2008). More recently other pioneering mobile phone innovations have been launched in the Philippines such as G-Cash, a mobile phone application which allows users to send remittances bypassing banks or other traditional intermediaries. G-Cash is effectively mobile money (like Kenya's M-Pesa) and was one of the first such applications to be launched globally (in 2004) precisely to meet the large demand for remitting money to the Philippines. It now has a range of wider uses reminding us that it is not just new media which have consequences for migration - the reverse is also true.

Both major telecommunication companies, Globe and Smart, have dedicated departments for product development and marketing for overseas populations. Globe's marketing strategy for the OFW market included slogans such as: "With Globe's Worldwide Services, the family will always be together." [Palagi buo ang 
pamilya.] And: "Christmas is more colorful and happier when the family is together." Or: "With Globe, you're always together." These slogans were also echoed by one their senior managers who stated in an interview: "We keep [the OFW families] together”. Both companies have extensive advertising campaigns which dominate the national media especially in the weeks before Christmas and other national holidays when migrants typically return to visit their families.

Turning migrants into a market and branding migration as a source of national development and pride as the government does, is a neoliberal fantasy where economic gain and consumption power are given priority over other social values. New media from mobile phones to webcam - both private resources - are seen as the solutions to social problems. Crucially, the availability of transnational communication is increasingly taken for granted and serves as a justification for otherwise socially contested decisions. Both state and corporate discourses seem to suggest that if new media can alleviate the social cost of family separation which comes with migration then migrating with new media is no longer a problem. The synergy between state and mobile phone companies is evident at many levels including in the sponsoring of various government events by the telecommunications companies. Globe, for instance, sponsors OWWA's “Model OFW Family of the Year" competition which recognizes a financially successful migrant family whose members maintain close family ties despite separation. This competition seems to encapsulate the neoliberal ideology of the government of the Philippines with its emphasis on economic gain and individualism cloaked under a veil of ethical responsibility (Ong 2006).

Do these public discourses about media and migration have any resonance in the experiences of migrants themselves and their left-behind families? Is the optimism surrounding new media justified when assessing the success of transnational communication? The following two sections provide answers to this question.

\section{The migrants' perspective}

Migrant women expressed much enthusiasm about the arrival of new media as they afforded them opportunities to perform "intensive mothering at a distance" (Madianou 2012). How this intensive mothering is performed depends on the age of the children. For example, mothers with infants or younger children found webcam invaluable as it allowed them to sustain a communication which would never have been possible on the phone as children appreciated the visual aspect of webcam. Mothers were also very keen to be able to see their children during a period of rapid development. The visual affordance of webcam also allowed mothers to be recognized by their children as mothers. The importance of this becomes evident once we contrast it to the past situation of letter writing when mothers 
returned to the Philippines after two or more years' abroad and their children would no longer recognize them. Sandra, a domestic worker in her 40s and mother of two described herself as an "incomplete mother" during that earlier time.

More media and platforms are introduced as the children grow older and we see that women tend to prefer certain media for certain purposes - for example IM was popular for helping with homework. Generally speaking mothers would invest a significant proportion of their income and time to fulfil their communication needs which were often regarded as a priority. Many participants knew a tremendous amount of detail about their children's daily lives, ranging from what their children had for dinner and how many hours they slept to the feedback on their latest school assignment. Apart from opportunities for intimacy and care at a distance new media also afforded opportunities for surveillance and monitoring. Donna, for example, routinely scours Facebook for any evidence or cue that can reveal aspects of her sons' lives. At a more fundamental level the increased social cues afforded by a combination of media provide migrant women with evidence of life back home. The contrast with the past situation is again striking. Whilst in previous years migrants often returned home only to find that their remittances had been misspent, today they feel much more in control "as they can see with their own eyes" whether their children are being well-fed and dressed or whether the repairs to the house are progressing. Being aware of the situation back home is not always a happy affair - women are often drawn into family feuds and conflicts - but participants expressed a preference to know than to be unaware. As Nora said, "This way I can do something about [the problems]".

Many participants reported that frequent communication often amplified conflict - if not with their children, then with other family members. While in the past problems were often swept under the carpet and never reported in letters, it is much harder today to keep family secrets. This is not the only burden of communication: women reported that the requests for help intensified putting a strain on their resources. Crucially, every mediated interaction is a reminder of the distance involved and the fact that "you can't hug your children" (Donna). This perhaps explains why many Skype calls end in tears.

\section{The left-behind families' perspective}

If mothers were enthusiastic about new technologies, their left-behind children were markedly more ambivalent about the success of transnational communication. Rather strikingly, the sample was divided into two: those for whom new media worked well and who reported an improvement in relationships post-migration; and those for whom the use of new media for keeping in touch with their parents represented a deterioration in the quality of the relationship. The latter group share a number of characteristics pointing to three variables that determine 
the success of transnational communication. Most of those for whom new media did not work were very young (typically under 10 years old) at the time of their mothers' migration. This was a time when communication was infrequent and expensive - letters took up to a month to arrive while phone calls were prohibitively expensive. It seems that during this time a gap was formed that was hard to fill even with the advent of new media. The third factor is the quality of the pre-existing relationship.

In fact, new media and the frequency of communication they engendered often brought to the surface problems or family disputes which had been long concealed and therefore increased conflict. The story of Reno illustrates this: at the age of 14 Reno dropped out of school. He stayed at home all day playing video games and watching television to the dismay of his elderly grandmother and 16-year-old sister who was effectively his carer. Neither the sister nor the grandmother dared break the bad news to the migrant mother so as not to upset her. After all, the reason she migrated was to provide a better education for her two children. The mother eventually figured out the truth with help from Yahoo Messenger where she noticed her son's status was “on” during school-time. This - entirely mediated revelation unleashed a series of arguments which would not have taken place without the cues accidentally given out by a platform.

More common were the complaints from left-behind children who for years experienced infrequent and pre-planned communication with their parents. The arrival of mobile phones and Internet platforms changed all that. Communication became frequent and spontaneous which was experienced as intrusion and monitoring by those teenagers or young adults who felt that their parents suddenly entered their lives after many years of silence. Needless to say the mothers' frequent calls or Facebook messages were not always welcome and much effort was expended on how to avoid such communication (often by switching to different media, an example of polymedia communication).

By contrast, those for whom new media worked were older at the time of their mothers' migration (usually in their teenage years). Age perhaps helps to understand the reasons a parent is migrating. That was usually after the arrival of new media, at least mobile phones, which meant that communication was more frequent and affordable. These teenagers also reported a strong bond with the mother prior to her departure. The parents' migration afforded the teenagers with increased autonomy and enabled them to flourish independently. At the same time the availability of media provided them with the emotional security and warmth needed at a time of rapid changes and challenges. Cecilia, for example, developed a very close bond with her mother following her migration. The two women would go shopping together (by visiting the same sites whilst on Skype) and send pictures of their clothes as attachments. Cecilia used webcam to care for her mother when she developed a serious illness. During the long calls she shared all personal secrets with her regarding her own relationships. The fact that both women related 
to each other outside the routines and chores of everyday life transformed their relationship into a kind of "pure relationship" (Giddens 1991) existing mainly for their mutual enjoyment.

Comparing the migrant mothers' and left-behind children's perspective reveals that new media cannot solve the problems of family separation. While for some families new media constitute solutions, for others they reveal or accentuate problems which had hitherto been concealed. New media can even accentuate conflicts and appear to deteriorate relationships. What emerges clearly is that media become constitutive of how relationships are enacted and experienced (a point further developed in Madianou and Miller 2013). Apart from this constitutive role of media in the experience of relationships there appears to be a further consequence for the process of migration as a whole. To understand this we need to return to the mothers' perspective.

\section{Sorting the puzzle}

At the early stages of this research we were faced with a puzzle: why did our participants prolong their stay in the UK when some of the key economic reasons that propelled them to migrate had been dealt with? Why did they not return when the loan was repaid, or when the house was finally built? Why did they choose to extend their stay in London or Cambridge given how much they missed their children? After all they often described themselves as temporary migrants, echoing the words and policies of their own government. Finding an answer to this puzzle became important as it seemed inevitably connected to the key question the research sought to answer which is about the nature of these long distance mediated relationships.

In order to answer this puzzle we need to look into participants' personal trajectories and wider migratory experience. Through the ethnographic encounter it was possible to find out not only about family members' uses of media but also about participants' personal histories, relationships, aspirations and how all these fed into the project of migration: the motivations for migration, the reasons for returning to the Philippines or settling abroad, and the ways in which such decisions were justified.

Examining the motivations for migration revealed that the decision to migrate was usually the result of a convergence of factors. Apart from the well-documented economic motivations (which ranged from situations of urgent need to aspirations of home ownership and better schooling for one's children) we found a plethora of social and other personal motivations including the desire for self-improvement and autonomy (see Madianou 2012). Almost invariably economic reasons would be coupled with other personal motivations. Such personal motivations need to be understood in the context of gender power relationships in the Philippines which 
many of our participants had found oppressive in the context of their personal relationships. It is thus not surprising that many participants experienced migration as empowering and spoke very positively of their time in the UK despite the fact that many had also experienced situations of exploitation and hardship (see Madianou 2012 for an extended discussion). As one of my participants told me: "My family only started listening to me after I started sending remittances". Unsurprisingly, many women were reluctant to give up their newfound status and sense of personhood once their contracts came to an end. So many of our participants decided to prolong their migration and continue to stay in the UK despite the fact that the most compelling economic factors that catalysed their migration had been dealt with. Although migration to the UK is considered officially to be short-term (according to the Philippine government), it appears to be gradually turning into a long-term migration or diaspora.

If the real reason for prolonging one's stay is to retain one's independence and autonomy then this is not easily articulated in social contexts. Recall that female migration and the attendant family separation are still contested within the Philippines despite government policies which encourage migration. Interestingly, participants decided to justify their decisions by referring to their newfound ability to mother at a distance through new media. Nelia, a domestic worker and mother of a young boy told me: "It's the right decision for me - as long as I keep sending money and as long as I keep calling them". "Calling” or practising "intensive mothering through new media”, whether successfully or unsuccessfully, provides women with a socially acceptable justification for their decisions which are deeper and more personal. That this justification is publicly available and even dominant among government agencies and telecommunication companies only helps to reinforce its credibility.

It is not possible to say whether it was migrants themselves or other actors such as the state or the market who first adopted the optimistic discourse about the power of media to "keep the family together". As is often the case, there is mutual reinforcement and not necessarily a casual relationship. Migrants appropriate new media in creative ways and leave the webcam on for hours; companies realize the market potential; governments seek to present a solution for social problems generated by flawed economic policies while in turn migrants seek justification for their personal decisions. I would not assume, however, that migrant women are simply influenced by the neoliberal ideologies of the Philippine government (Padios 2011). The predicament of female migrants is incredibly complex as they have to negotiate not only neoliberal ideologies and conditions of labour exploitation, but also asymmetrical gender power relationships exacerbated by normative expectations of motherhood (Madianou 2012). Many participants experienced violence or humiliation in their personal relationships and these experiences were important catalysts for migration. It is not surprising then that for these women migration can be a source of empowerment and reinvention despite the 
associated hardships and exploitation. Branded simultaneously as "heroes of the economy" and "exploited workers"; "bad mothers" and "light of the home"; "breadwinners" and "caregivers" I argue it's more important to listen to the voices of the women themselves and how they negotiate these contradictory positions.

\section{The mediatization(s) of migration}

What emerges from the analysis is that the taken-for-grantedness of personal communication at a distance is beginning to contribute to the shaping of the wider phenomenon of migration itself. Migrant women justify decisions relating to migration as well as decisions relating to the prolongation of their stay on the availability of transnational communication. Even though new media will not solve problems that are fundamentally social, the fact that they are perceived as solutions to the problems of separation reveals their significant power to contribute to the shaping of the phenomenon of migration. The availability of cheap and instant communication is not the reason why women migrate or why they prolong their stay - there are strong personal and social reasons why they choose to do so. But the availability of transnational communication makes these decisions socially acceptable. The fact that institutions dealing with migration have adopted discourses that highlight the taken-for-grantedness of new media further entrenches these views. As a result we see that new media and migration become enmeshed as is evident in lowering thresholds for migrating or settling in the UK and thus changing migration patterns. New media are more than channels for communication as they contribute to the transformation of migration as a phenomenon.

Although media are more than channels for communication, they are clearly also serving the purpose of interpersonal communication. The wider structural changes are made possible through the micro-processes of mediated interactions which are analysed here as mediation. It is the perpetual and taken-for-granted mediated everyday communication, sometimes banal, other times fraught that sustains social change. Polymedia provides a framework to unpack the ways in which users navigate the environment of media and thus exposes the inner workings of mediation. The research revealed that mothers and their left-behind children managed their relationships through their choice of media. Choosing a platform over another from within the menu of available media opportunities acquired communicative intent and became constitutive of their relationships.

The findings reported here about mediatized migration do not necessarily apply to all kinds of migrations. Migration is not a homogenized phenomenon. There is no single type of migration but there are several social, political, economic, gender, and cultural factors which determine migration flows and migrant experiences. Being an economic migrant from the Philippines differs fundamentally from being a refugee or asylum seeker from a war-torn country. The migrant 
flow addressed here was characterized by family separation at a primary level and systematic transnational communication. It is the frequent, almost ubiquitous communication at a distance that sustained and influenced the wider structural transformations. The argument presented here is only likely to be relevant to other migrations that share this fundamental characteristic as well as some of the other structural parameters.

Apart from developing an argument about the mediatization of migration this chapter proposed a distinctive approach to mediatization which draws on media anthropology. The chapter has traced parallels between the two traditions and argues that there is scope for theoretical convergence. The ethnographic approach proved to be invaluable in uncovering social change. The finding about mediatized migration was not a clear research hypothesis or foretold conclusion. It emerged through the long-term engagement with my participants and through the investigation of different stakeholders, from government agencies to mobile phone companies themselves. At this point it's worth reflecting on what an anthropological approach to mediatization would include: first, a wide lens approach, investigating not just the uses of media but also the wider social context. For this particular study this meant investigating the motivations for migration and the reasons for prolonging migration as well as how such decisions were justified (not the same thing!). It also meant investigating the family relationships in question as well as the wider social norms regarding family life and parenting. This wide lens approach requires research to include a wide range of relevant stakeholders or actors: from the research participants to representatives of institutions and organizations relevant to the research.

Second, a historical perspective; ethnography is often considered as too preoccupied with the present. That is not accurate and there is a plethora of ethnographies, including media ethnographies (see Larkin 2002), which encompass a historical approach. A diachronic perspective matters particularly in research on social change and our present study included an oral history of how people remembered the past situation of communication via letters and cassette tapes. The contrast with this period of scarce and expensive communication was particularly revealing of changes brought about by new communication technologies.

Related to this point about temporality is the importance of a long-term perspective. Many participants in this research were interviewed more than once, while 13 participants have been key informants with whom I have maintained social relationships for over six years. Anthropologists typically work in a geographical area, or with a group of people, and will often argue that fieldwork is largely about maintaining social relationships. This long-term involvement has provided me with unparalleled insight into the lives and relationships of these people who I have come to know as friends.

Fourth, being able to improvise and "to follow the thing" is important - fieldwork is like a solving a mystery, full of surprises and unexpected twists (see also 
Strathern 1996). These should be welcomed for their revelatory potential. The unpredictability of the research findings and the flexibility to adapt to events as they present themselves is one of the reasons why ethnographic research is well suited for capturing social change particularly on sensitive topics where vital issues will not be expressed in an interview, but in practices or decisions.

Finally, a comparative perspective. This research benefited from data from the Philippines and the UK. Focusing only on one empirical site would have produced an entirely different set of conclusions. An empirically grounded study of mediatization of migration would ideally need to extend these comparisons to different migrant populations, migration patterns as well different destinations/host societies. This will allow for the disaggregation of factors relating to sending countries, receiving countries, legal frameworks, and media environments which will contribute to theory building and the further understanding of the deeper social consequences of the media. So although the thesis presented here may have wider applicability in different empirical contexts it is understood as only the beginning of a larger project of new media environments, migration and social change.

\section{References}

Acacio, Kristel. 2008. Managing labor migration: Philippine state policy and intenational migration flows, 1969-2000. Asian and Pacific Migration Journal 17: 103-132.

Arellano-Caradang, Maria Lourdes, Beatrix A. Sison and Christopher Caradang. 2007. Nawala Ang Ilaw Ng Tahanan, case studies of families left behind by OFW mothers. Manila: Anvil.

Asis, Maruja M. B. 2008. The Philippines. Asian and Pacific Migration Journal 17(3-4): 349-378.

Baldassar, Loretta. 2008. Missing kin and longing to be together: Emotions and the construction of co-presence in transnational relationships. Journal of Intercultural Studies 29(3): 247266.

Baym, Nancy. 2010. Personal Connections in the Digital Age. Cambridge: Polity.

Benson, Rodney. 2013. Shaping Immigration News. A French-American Comparison. Cambridge: Cambridge University Press.

Berger, Peter L. and Thomas Luckmann. 1967. The Social Construction of Reality: A Treatise in the Sociology of Knowledge. London: Penguin.

Castles, Stephen and Mark Miller. 2009. The Age of Migration. London: Palgrave.

Clark, Lynn Schofield. 2012. The Parent App. Oxford: Oxford University Press.

Constable, Nicole. 2009. At home but not at home: Filipina narratives of ambivalent returns. Cultural Anthropology 14(2): 203-228.

Couldry, Nick. 2012. Media, Society, World: Social Theory and Digital Media Practice. Cambridge: Polity.

Couldry, Nick and Andreas Hepp. 2013. Conceptualizing mediatization: Contexts, traditions, arguments. Communication Theory 23(3): 191-202.

Deuze, Mark. 2012. Media Life. Cambridge: Polity

Diminescu, Dana. 2008. The connected migrant: an epistemological manifesto. Social Science Information 47(4): 565-579.

Elias, Nelly and Dafna Lemish. 2009. Spinning the web of identity: the roles of the internet in the lives of immigrant adolescents. New Media and Society. 11(4): 533-551. 
Franklin, Marianne I. 2001. Inside out: postcolonial subjectivities and everyday life online. International Feminist Journal of Politics 3(3): 387-422.

Fortunati, Leopoldina, Raul Pertierra and Jane Vincent (eds. ). 2012. Migrations, Diaspora and Information Technology in Global Societies. London: Routledge.

Georgiou, Myria. 2006. Diaspora, Identity and the Media. Cresskill, NJ: Hampton Press.

Giddens, Anthony. 1991. Modernity and Self-Identity. Cambridge: Polity.

Gillespie, Marie. 1995. Television, Ethnicity and Cultural Change. London: Routledge.

Ginsburg, Faye, Lila Abu-Lughod and Brian Larkin (eds.). 2002. Media Worlds: Anthropology on New Terrain. Berkeley: University of California Press.

Guibernau, Montserrat. 2010. Migration and the Rise of the Radical Right. London: Policy Network Paper.

Hartmann, P. and C. Husband. 1974. Racism and the Mass Media. London: Davis and Poynter.

Hegde, Radha (ed.). 2011. Circuits of Visibility. New York: New York Press.

Hepp, Andreas. 2012. Mediatization and the 'moulding forces' of the media. Communications 37(1): 1-28. doi: 10.1515/commun-2012-0001.

Hepp, Andreas. 2013. Cultures of Mediatization. Cambridge: Polity Press.

Hiller, Harry and Tara Franz. 2004. New ties, old ties and lost ties: the use of the internet in diaspora. New Media and Society 6(6): 731-752.

Hjarvard, Stig. 2008. The mediatization of society. A theory of the media as agents of social and cultural change. Nordicom Review 29(2): 105-134.

Hjarvard, Stig. 2013. The Mediatization of Culture and Society. London: Routledge.

Hochschild, Arlie. 2000. Global care chains and emotional surplus value. In: Will Hutton and Anthony Giddens (eds.), On The Edge: Living with Global Capitalism, 130-146. London: Jonathan Cape.

Hondagneu- Sotelo, Pierrette and Ernestine Avila. 1997. "I'm here, but I'm there": The meanings of Latina transnational motherhood. Gender and Society 11(5): 538-571.

Horst, Heather, Becky Herr-Stephenson and Laura Robinson. 2010. Media ecologies. In: Mizuko Ito et al., Hanging out, Messing Around and Geeking out: Kids Living and Learning with New Media, 32-78. Cambridge, MA: MIT Press.

Horst, Heather and Daniel Miller. 2006. The Cell Phone: An Anthropology of Communication. Oxford: Berg.

Horst, Heather and Daniel Miller (eds.). 2012. Digital Anthropology. Oxford: Berg.

Husband, Charles. 2005. Minority ethnic media as communities of practice: professionalism and identity politics in interaction. Journal of Ethnic and Migration Studies 31(3): 461-479.

Hutchby, Ian. 2001. Technologies, texts and affordances. Sociology 35: 441-456.

Jha, Shikha, Guntur Sugiyarto and Carlos Vargas Silva. 2009. The Global Crisis and the Impact on Remittances to Developing Asia. Economics Working Paper Series.

Kaye, Ronald. 2001. Blaming the victim: an analysis of press representation of refugees and asylum seekers in the United Kingdom in the 1990s. In: Russell King and Nancy Wood (eds.), Media and Migration, 53-70. London: Routledge.

Kosnick, Kira. 2007. Migrant Media. Bloomington: Indiana University Press.

Krotz, Friedrich. 2009. Mediatization. A concept with which to grasp media and societal change. In: Knut Lundby (ed.), Mediatization: Concept, Changes, Consequences, 19-38. New York, NY: Peter Lang.

Larkin, Brian. 2002. Materializing culture: cinema and the creation of social space in media worlds. In: Faye Ginsburg, Lila Abu-Lughod and Brian Larkin (eds.), Media Worlds: Anthropology on New Terrain, pp. 319-336. Berkeley: University of California Press.

Livingstone, Sonia. 2009. On the mediation of everything. Journal of Communication 59(1): 1-18. Loshitzky, Yosefa. 2010. Screening Strangers: Migration and Diaspora in Contemporary European Cinema. Bloomington: Indiana University Press. 
Lundby, Knut. 2009a. Media logic: looking for social interaction. In: Knut Lundby (ed.)

Mediatization: Concepts, Changes, Consequences, 101-119, New York: Peter Lang.

Lundby, Knut (ed.). 2009b. Mediatization: Concepts, Changes, Consequences. New York: Peter Lang.

MacKenzie, Donald and Judy Wajcman. 1999. Introductory essay. In: Donald MacKenzie and Judy Wajcman (eds.), The Social Shaping of Technology ( $2^{\text {nd }}$ ed.), 3-27, Buckingham: Open University Press.

Madianou, Mirca. 2005a. Mediating the Nation: News, Audiences and the Politics of Identity. London: UCL Press/Routledge.

Madianou, Mirca. 2005b. Contested communicative spaces: identities, boundaries and the role of the media. Journal of Ethnic and Migration Studies 31(3): 521-541.

Madianou, Mirca. 2011. Beyond the presumption of identity? Ethnicities, cultures and transnational audiences. In: Virginia Nightingale (ed.), Handbook of Media Audiences, 444-458. Malden, MA: Blackwell.

Madianou, Mirca. 2012. Migration and the accentuated ambivalence of motherhood: the role of ICTs in Filipino Transnational Families. Global Networks 12(3): 277-295.

Madianou, Mirca. 2014. Smartphones as polymedia. Journal of Computer-Mediated Communication 19(3): 667-680.

Madianou, Mirca. in preparation. The tangibility of networks.

Madianou, Mirca and Daniel Miller. 2012. Migration and New Media: Transnational Families and Polymedia. London: Routledge.

Madianou, Mirca and Daniel Miller. 2013. Polymedia: towards a new theory of digital media in interpersonal communication. International Journal of Cultural Studies 16(2): 169-187.

Marcus, George E. 1995. Ethnography in/of the world system: The emergence of multi-sited ethnography. Annual Review of Anthropology 24: 95-117.

Martín-Barbero, Jesus. 1993. Communication, Culture and Hegemony. London, England: Sage.

Miller, Daniel and Don Slater. 2000. The Internet: An Ethnographic Approach. Oxford: Berg.

Mitra, Ananda. 2001. Marginal voices in cyberspace. New Media and Society 3(1): 29-48.

Moore, Kerry, Bernhard Gross and Terry Threadgold (eds.). 2012. Migrations and the Media. New York: Peter Lang.

Ong, Aihwa. 2006. Neoliberalism as Exception: Mutations in Citizenship and Sovereignty. Durham, NC: Duke University Press.

Padios, Jan Maghinay. 2011. Dial C for Culture: telecommunications, gender and the Filipino transnational gender market. In: Radha Hegde (ed), Circuits of Visibility, 212-230. New York: New York Press.

Parreñas, Rhacel. 2001. Servants of Globalization. Women, Migration and Domestic Work. Stanford: Stanford University Press.

Parreñas, Rhacel. 2005. Children of Global Migration. Stanford: Stanford University Press.

Parreñas, Rhacel. 2008. The Force of Domesticity. New York: New York Press.

Pertierra, Raul. 2010. The Anthropology of New Media in the Philippines. Manila: Ateneo de Manila University Press.

Philo, Greg, Emma Briant and Pauline Donald. 2013. Bad News for Refugees. London: Pluto Press. POEA. [2005] Overseas Employment Statistics. Manila: POEA

POEA. [2009] 2008. Overseas Employment Statistics. URL http://poea.gov.ph/stats/ stats2007.pdf. Consulted 19 March 2010

Portes, Alejandro and Ruben G. Rumbaut. 2006. Immigrant America, a portrait, $3^{\text {rd }}$ ed. Berkeley: University of California Press.

Qiu, Jack. 2009. Working-Class Network Society. Cambridge, Mass: MIT Press.

Reuters. 2008. http://www.reuters.com/article/idUS94568+09-Jan-2008+PRN20080109 Last

consulted: 22 November 2012 
Robins, Kevin and Asu Aksoy. 2001. From spaces of identity to mental spaces: lessons from Turkish-Cypriot cultural experience in Britain. Journal of Ethnic and Migration Studies 27(4): 685-711.

Siapera, Eugenia. 2005. Minority activism on the Web: between deliberative democracy and multiculturalism. Journal of Ethnic and Migration Studies 31(3): 499-519.

Silverstone, Roger. 1999. Why Study the Media. London: Sage.

Silverstone, Roger. 2005. Mediation and communication. In: Craig Calhoun, Chris Rojek and Bryan Turner (eds.), Handbook of Sociology, 188-207. London: Sage.

Sreberny, Annabelle. 2005. 'Not only, but also': mixedness and media. Journal of Ethnic and Migration Studies 31(3): 443-460.

Strathern, Marilyn. 1996. Cutting the network. Journal of the Royal Anthropological Institute 2(3): 517-535.

Sun, Wanning. 2009. Maid in China: Media, Morality and the Cultural Politics of Boundaries. London: Routledge.

Sun, Wanning. 2011. Maid as metaphor: Dagongmei and a new pathway to Chinese transnational capital. In: Radha Hegde (ed.), Circuits of Visibility, 196-211. New York: New York Press.

Thompson, John B. 1995. The Media and Modernity. A Social Theory of the Media. Cambridge: Polity.

van Dijk, Teun. 1991. Racism and the Press. London: Routledge.

Vertovec, Steven. 2004. Cheap calls: the social glue of migrant transnationalism, Global Networks 4(2): 219-224.

Wallis, Cara. 2013. Technomobility in China. New York: New York University Press. 
VI. Power, law and politics 
